\title{
Looted Art and Cultural Property; Current Controversies, Future Resolutions The Seventh Annual Conference of the Lawyers' Committee for Cultural Heritage Preservation New York City, 25 March 2016
}

The Lawyers' Committee for Cultural Heritage Preservation (LCCHP), a non-profit organization promoting the preservation and protection of cultural heritage through education and advocacy, hosts a full-day conference each year. This year's soldout conference, the seventh such conference in the history of the organization, was hosted at Fordham University School of Law in New York City and co-sponsored by the Fordham Art Law Society. Entitled "Looted Art and Cultural Property; Current Controversies, Future Resolutions", the event featured 18 speakers in four panels, a keynote address, and a lunchtime interview. The day's schedule included speakers from six different countries: the USA, Poland, Greece, Germany, Cyprus, and Slovenia.

The conference began with a welcome from LCCHP's current president, Thomas Kline, an attorney at Andrews Kurth. He introduced the keynote speaker, Larry Kaye, Co-Chair of Herrick Feinstein's prestigious Art Law Group. Mr. Kaye, who has over four decades of experience as an art attorney, spoke about the start of his career in the field. He discussed his first legal case, which began before he joined his law firm. The case 
was drawn out over many years and made Mr. Kaye keenly aware that lawsuits involving art objects can extend for over a decade. This perfectly illustrated the complexity of legal battles over art and cultural property and the time required to see them through completion. The time commitment is a factor that makes such litigation an unappealing aspect for many potential litigants. Litigation is not always the best means to find justice as the trial process is full of inequitable rules that prohibit victims from receiving his or her day in court. A case in point: the use of overly restrictive statutes of limitations which may bar a deserving claimant from obtaining an equitable remedy. In complex lengthy cases victims are often unable to pursue justice due to time restrictions, prohibitively expensive court fees and attorney fees, and procedural hurdles. In addition, victims are sometimes unable to pursue the restitution of art because of the nature of the works - stolen art remains hidden. In other instances, particularly in cases related to Nazi-looted art, victims may be unaware of objects stolen from their ancestors. How can an individual pursue restitution in a timely fashion when the theft itself is unknown to the person with standing to bring a case?

Due to this inequity, Mr. Kaye argued that litigation, and the procedural rules regulating litigation, may make it ill-suited to resolve conflicts involving art. Hence he urged the formation of a tribunal specifically designed to address art restitution matters. This type of alternative dispute resolution mechanism would enable matters to be resolved more rapidly, with fewer procedural barriers and with lower costs to the already-victimized individuals.

Following the keynote presentation, the first panel tackled perhaps the most controversial topic of the day - the proper place for the Parthenon Marbles. This quintessential and most hotly contested issue in the cultural heritage realm concerns whether the Parthenon Marbles should remain in the British Museum or be returned to Athens, Greece. To begin the discussion, Clemente Marconi, a professor from the History of Greek Art and Archaeology Department at New York University's Institute of Fine Arts, provided the historical context surrounding the significance of the Parthenon and its marbles in art history. He emphasized the importance and the historic story told in the Parthenon. Kevin Ray, Of Counsel at Greenberg Traurig, next examined legal issues related to the marbles. His analysis primarily focused on the purported permission that Lord Elgin received, in the form of a firman (i.e. edict), from the ruling Ottomans. However, he noted that the evidence surrounding the firman is scant, and that many posit that Elgin overreached the firman, if it even existed.

Irini Stamatoudi, General Director of the Hellenic Copyright Organization, Hellenic Ministry of Culture and Sports, presented the perspective of the Greek people and its Ministry. She spoke about the importance of the marbles to Greek heritage and identity, the need to unify them as a whole, and the contention that the British Museum does not rightfully own them, independent of whether or not the museum has possessed them for 200 years. James Cuno next argued that the 


\section{EVENTS AND CONFERENCES}

Editorial Report

marbles do not belong in Greece because they are an important part of the art history for the entire world to appreciate. He suggested that the marbles might be best suited for loans around the world to maximize their access to all of humanity. The audience posed questions to the panelists after the conclusion of their individual remarks.

The second panel, "Recent Developments in Cultural Heritage Restitution Cases: Where Are We And Where Are We Going?", constituted an opportunity to update the audience about some of the current developments in heritage issues. The panel began with Matthew Bogdanos, Assistant District Attorney, Manhattan, Colonel, United States Marine Corps Reserve, and author of "Thieves of Baghdad" discussing his experiences in Iraq. He described the widespread looting and destruction in the Middle East, the use of smuggled objects as currency, and the need to thwart the type of pillaging from within the communities. He entertained the audience with images of art and tales about his time recovering looted artifacts (and forgeries) in Iraq.

Pierre Ciric, Founder of the Ciric Law Firm, PLLC, then presented issues involving museums and their acquisition of potentially looted art. He emphasized that the importance of museums recognizing the values captured in the Washington Principles and ensuring that work acquired by these institutions not be loot. In addition he explained the role of the AAMD's (Association of Art Museum Directors') guidelines to ensure that loot does not enter collections. Howard N. Spiegler, Partner and Co-Chair of Herrick, Feinstein's International Art Law Group, next addressed legal issues in relation to a case handled by the law firm, Van Saher v. Norton Simon. He described the complex factual and legal history of the case, which has made it difficult for the rightful owners, the heirs of famed art dealer Jacques Goudstikker, to recovering their property from the Pasadena-based museum.

During the lunch session, Tom Kline interviewed individuals central to the development and application of the law and policy governing cultural property in the United States, Europe, the Middle East, and Southeast Asia. The following persons were included in the discussion: Susan De Menil, documentary filmmaker and President \& Director of Byzantine Fresco Foundation; Deborah Lehr, Director of the Antiquities Coalition; and Boguslaw Winid, Ambassador of Poland to the United Nations. They discussed recent developments and current legal and policy issues involved in the restitution of looted property, the protection of cultural property in areas of conflict or otherwise exposed to looting, and museum policy concerning the acquisition and display of cultural objects.

After lunch, a third panel further discussed looting and destruction during conflicts and examined the efficacy of current policies. This panel was reflective in nature, examining whether current policy is properly addressing the issues related to the phenomena of looting and destruction of cultural property. The diverse panel represented perspectives from different backgrounds: a government representative, an academic, an attorney in private practice, and a representative from a ma- 
jor auction house. Evan Ryan, the Assistant Secretary of State for Education and Cultural Affairs in the US State Department, discussed the actions taken in the US to cope with looting. Brian Daniels, Ph.D., Director of Research and Programs and lecturer in the Anthropology Department at the University of Pennsylvania, described his work on the ground in the Middle East. The University of Pennsylvania works with locals and heritage experts to monitor the situation, preserve sites, and make a record of the objects that are leaving the region. Kate Fitz Gibbon, an attorney with a private practice focusing on art, museum law, cultural heritage law, and estate planning, presented information about her practice. According to her, looted objects are not entering the market. She believes this to be true because dealers have not approached her with these materials for sale. Next Sandra Cobden discussed Christie's vetting process for avoiding the sale of looted objects. She recognized that the auction house has sold some objects of problematic provenance, a result of the sheer number of objects that are sent through the auction house and a lack of information in some cases. Nonetheless Christie's maintains a process for researching and vetting antiquities, and works with foreign nations to return works in clearly problematic cases.

The final panel of the day described the use of technology in issues related to heritage. Engineers and technical experts from Cyprus (Marinos Ioannides, Ph.D., Cyprus Technical University and Project Manager, Initial Training Network - Digital Cultural Heritage), Germany (Professor Dieter Fritsch, Institute for Photogrammetry at the Universitaet Stuttgart), and Slovenia (Professor Roko Žarnić, University of Ljubljana and co-coordinator of ECTP Focus Area Cultural Heritage $(\mathrm{FACH})$ ), who are working together on a project funded by the European Union (www.itn-dch.eu), explained the use of science and technology in the study, documentation, preservation, protection and display of cultural property. In their presentations the speakers demonstrated, with a high degree of precision, the tools created by engineers and technical experts to assist in the preservation and digitizing of heritage sites.

Following this final panel, attendees enjoyed a reception and the opportunity to mingle and interact with fellow professionals. As always, the LCCHP's annual conference provided its attendees with a selection of reading materials (all provided on a USB drive), opportunities to learn from other professionals, and a series of enlightening presentations and discussions. 